\title{
Reconstructing the Economy: A Methodological Journey from the Surface to the Essence and Back
}

\author{
Peter Karl Fleissner
}

\author{
fleissner@arrakis.es
}

\begin{abstract}
The essential methodology in social science to "understand" phenomena is informed abstraction. But the way how and what for the abstraction process is shaped - divides the economists into various schools. While mainstream economists abstract from any links of the economy to human beings - replacing them by selfish machines maximizing their profits or individual utilities, and neglecting any deeper analysis of the basic constructions they use (like prices or money), heterodox economists try to look behind the surface, link them to certain periods of history and to the source of all value: humans are social beings and cannot exist without mutuality. The paper presents a heterodox way to reconstruct contemporary capitalist economies by applying the new science of information with its evolutionary concepts. It starts the description on a very abstract level: useful things and services produced by specialized labor. Step by step new layers of economic activities and related information are added and become the basis for the next one. Vice versa economic activities on lower layers become controlled and modified by higher layers. One can see that the higher controlling principles in contemporary capitalist economies do not assist the economic, social, and cultural well-being of the majority of people, but function according to the self-interest of a minority. For the first time in history capitalism has developed new technologies that in principle could allow for the participation of the many, to create abundance of information, and to offer tools for building a democratic and sustainable society. But by the same capitalism, rigid Intellectual Property Rights and severe copy protection mechanisms enforce artificial shortage of information goods.
\end{abstract}

Keywords: information society, new science of information, heterodox economics, commodification of information goods, commercialization of information services, emancipation, simulation model

Acknowledgement: Herewith I express my gratitude to Wolfgang Hofkirchner for clarifying my rather chaotic ideas about contemporary societies and for providing me with valuable comments.

\section{Introduction}

This paper deals with methodological tools to analyze the contemporary economy within an emancipative perspective. The economy is seen as a sample of interlinked and hierarchically sorted layers of decreasing degree of abstraction. After their verbal and graphical description the basics of a mathematical representation are given, applying Leontief's input-output approach. (Leontief, 1966). Finally, pre-requisites for a transformation of the present economies towards the emancipation of labor and higher sustainability are discussed.

The paper starts with Marx' most abstract concept of use values. They are independent of any specific type of relations of production. It needs Marx' concept of labor value to construct a virtual economy of self-employed who are the owners of their products. On this level we already use the concepts of commodity markets and competition.

To come to a more realistic description of contemporary economies we have to include features and effects of capitalism. Therefore, in a third step we allow for fixed capital, wage labor, and competition between capitalists. Exploitation, profit and accumulation come into sight. Work becomes a marketable good. Mathematically this means to solve the transformation problem from labor values to prices of production (both have to be expressed in the same units, either labor time or prices). If the total value of output is assumed to remain constant before and after the transformation, it can be shown (Fleissner, 2008, p. 383) that any feasible price system can be found on a hyperplane of $k-1$ dimensions ( $k$ is the number of sectors of the economy).

All these concepts implemented up to now take only the primary distribution into account, which is created by the markets. To end up with the more realistic secondary distribution we have to include banks, money, credit, debt and interest rates and their redistributive effects. Adding the pub- 
lic sector it becomes possible to compare the theoretical construction with real data. On this layer we find tax rates, public spending, social insurance contributions and corresponding transfer processes and the redistributive effects of the tax and transfer system.

During the recent decades digital information and communication have changed the character of capitalism again. Traditional players leave the market, new ones enter. New possibilities for the shaping of capitalism open up, but also possibilities for a new type of society, democratically controlled.

\section{The Focus of Economics}

Although mainstream economics usually sees the economy as a flat entity with many indicators one can measure on the surface, the whole story might be more complex than that. Like in any science also in economics one could - guided by Karl Marx - assume that the foundation of any science is given by rather abstract principles. From there step by step we can approach more realistic layers up to the moment where the full picture of the surface of the field under investigation is reached.

In physics we have a nice example to illustrate this approach. Galileo Galilei has shown that gravitation accelerates all objects at the same rate, but if we test this proposition empirically, we find that a feather and a metal sphere will fall down with different speeds. To explain the real movements of the feather we have to add further laws, like aerodynamics or theories of friction etc. Here we use the same methodological guidelines and apply them to an existing economy.

Figure 1 illustrates the steps we can undertake. Layer 1, represented in the lower left corner of fig. 1 gives the material/energy basis of any economy in history. This basis is even necessary for animal communities. We start our journey through the various layers of the economy by these human made artifacts, result of a transformation of natural resources into cultural artifacts by work. From there the economy can be seen to produce use values (useful things produced or activities undertaken by people). If we put use values into the focus of our approach we abstract at the same moment from markets, from labor, from prices, from wages, from capital, from money, from power relations, from governance etc. We abstract from anything social development and the interaction of people have added over history.

This is an opposite method mainstream economists have applied. In their models they represent products of certain kinds as abstract goods and services. They stripped them of all their physical aspects. In their economic concepts goods do not have any weight, any chemical composition, any detrimental effects to our health; they just have a price and a measure of their multiplicity, a number or an index. But in reality the physical/energetic aspects of goods are important - given the chronic shortage of certain materials, peak oil, non-renewable resources, solid or liquid or radioactive waste etc.

What classical economists like Karl Marx (1979) in "Das Kapital", volume one, and Adam Smith (1789, German reprint 1978) have added to the abstract view of goods is their social origin. They believed that the prices of goods are proportional to labor expended (exchange values). Human labor is the precondition for taking care of others and by that assuring the survival and development of humankind. But this care taking rests on mutuality ("do ut des"). We interpret their writings as a description of an economy where markets are established as a consequence of the division of labor. Competition is there and makes the individual contributions of work to the economy comparable with the social average. The exchange of goods against money echoes this mutual care among people on the level of market economies, and money becomes a societal symbol of human labor. Such arguments are neglected by Western mainstream economists. 


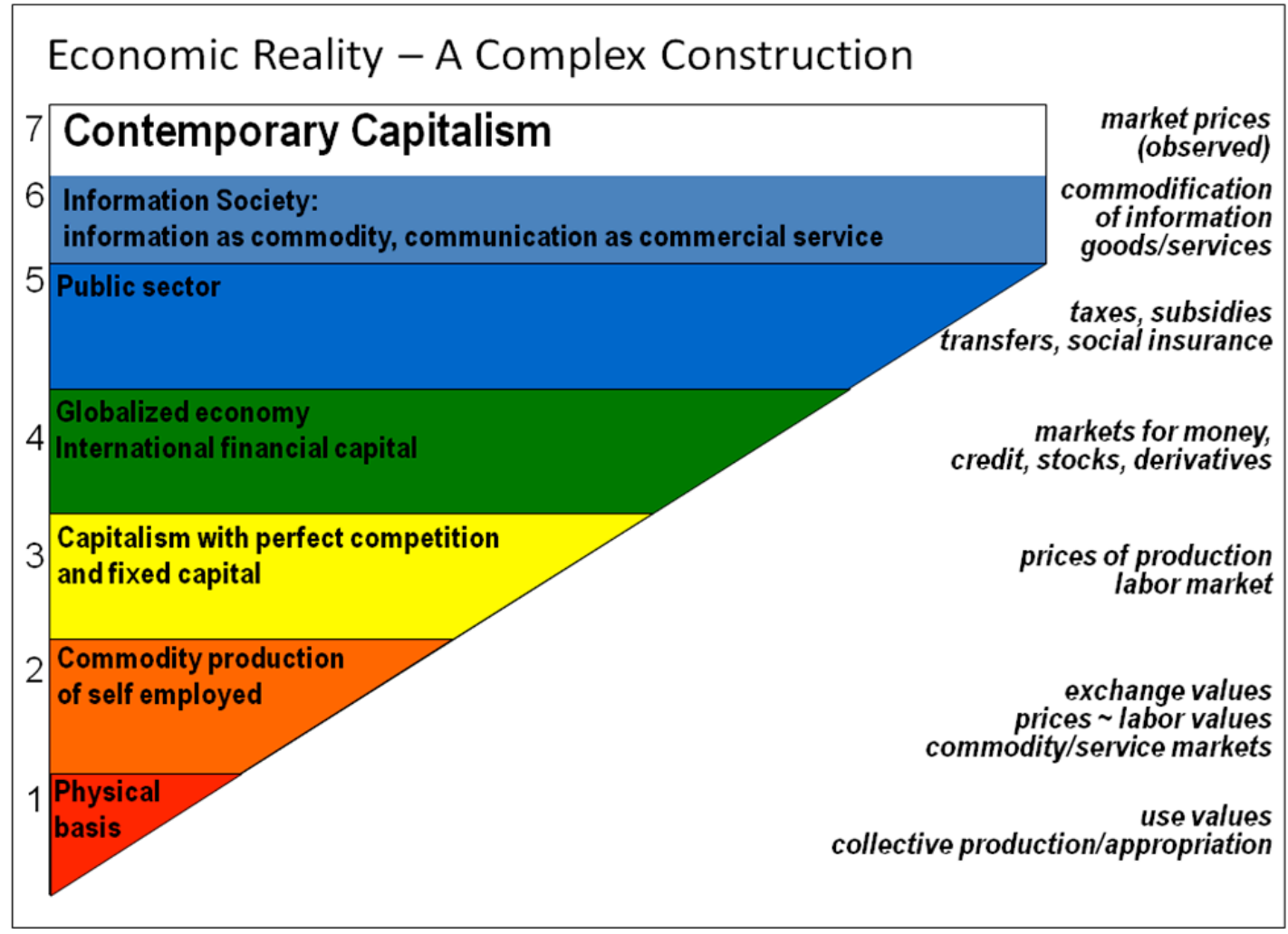

Figure 1: The Economy - a complex construction

Figure 1 can be read in two different ways: It can be seen as a scheme of logic, representing various, but ordered degrees of abstraction, but it could also be seen as a roadmap of the evolution of the economy over history. This double meaning is illustrated by layer 1 of figure 1 . As a scheme of logic, layer 1 abstracts from particular social relations between producers and is therefore compatible with any form of social relations. It is compatible with collective production as well as with feudal, capitalist or socialist types of economies. But we could also look at layer 1 as representing not only a scheme of logic but as a certain phase of an evolutionary economic process in history: Probably the early economies were based on collective production and collective appropriation. In this way we can relate the scheme of logic to its historic roots (see right column of fig. 1). As a logic scheme layer 1 means the material precondition of any economy, as historic scheme it represents also early social relations of production.

The second layer can be understood as the reproduction of self-employed laborers. Figure 2 represents this layer graphically as a dynamic loop between production, laborers and consumption. By selling their products (results of their own work) on the market at a price proportional to the social necessary labor time laborers get money back and are able to buy consumer goods for their own reproduction. This layer symbolizes the mutuality of people and their dependence on the activities of the others. The first layer of use values is a necessary precondition for the second one. But with the emergence of layer 2 the economy is controlled by individual skills that are compared with the social average, by actually existing consumption levels, and by specific market and environmental conditions. The market is a market of goods only, and should allow for the reproduction of the laborers. Layer 2 of figure 1 as well as loop A in figure 2 abstract from fixed capital, capitalists, and wage labor. Engels interpreted this type of an economy with self-employed laborers selling their products at prices proportionate to their direct and indirect labor content. The relations of production on this level are relations between small commodity producers.

The third layer in figure 1 and loop B in figure 3 bring capitalists into the picture. A second feedback-loop is created (see loop B in figure 3). Part of the wealth created by workers is now redi- 
rected to capitalists. The (former) self-employed laborers become now workers and earn wages and salaries. Capitalists receive profits as result of their activities, accumulate physical capital and innovate technology and organization.

Feedback-loop B is qualitatively different from loop A: While consumption of workers more or less depends on the levels technology and distribution of wealth have reached, capitalists are in a position to increase their capital by accumulation.

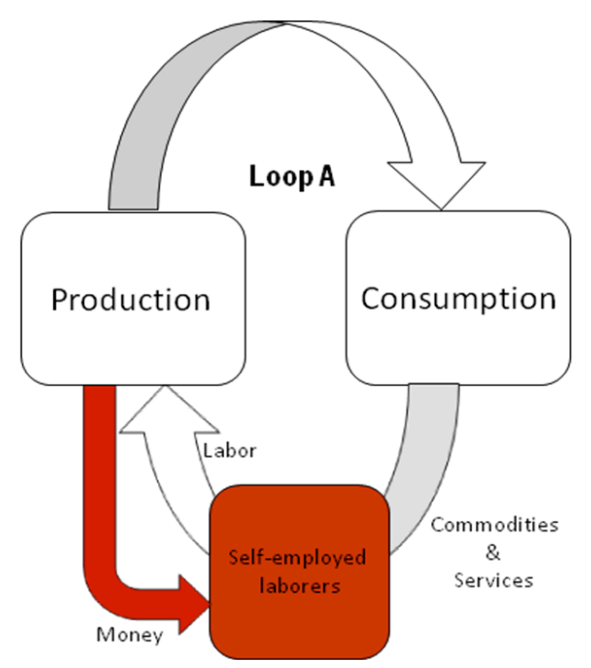

Figure 2: Reproduction of laborers

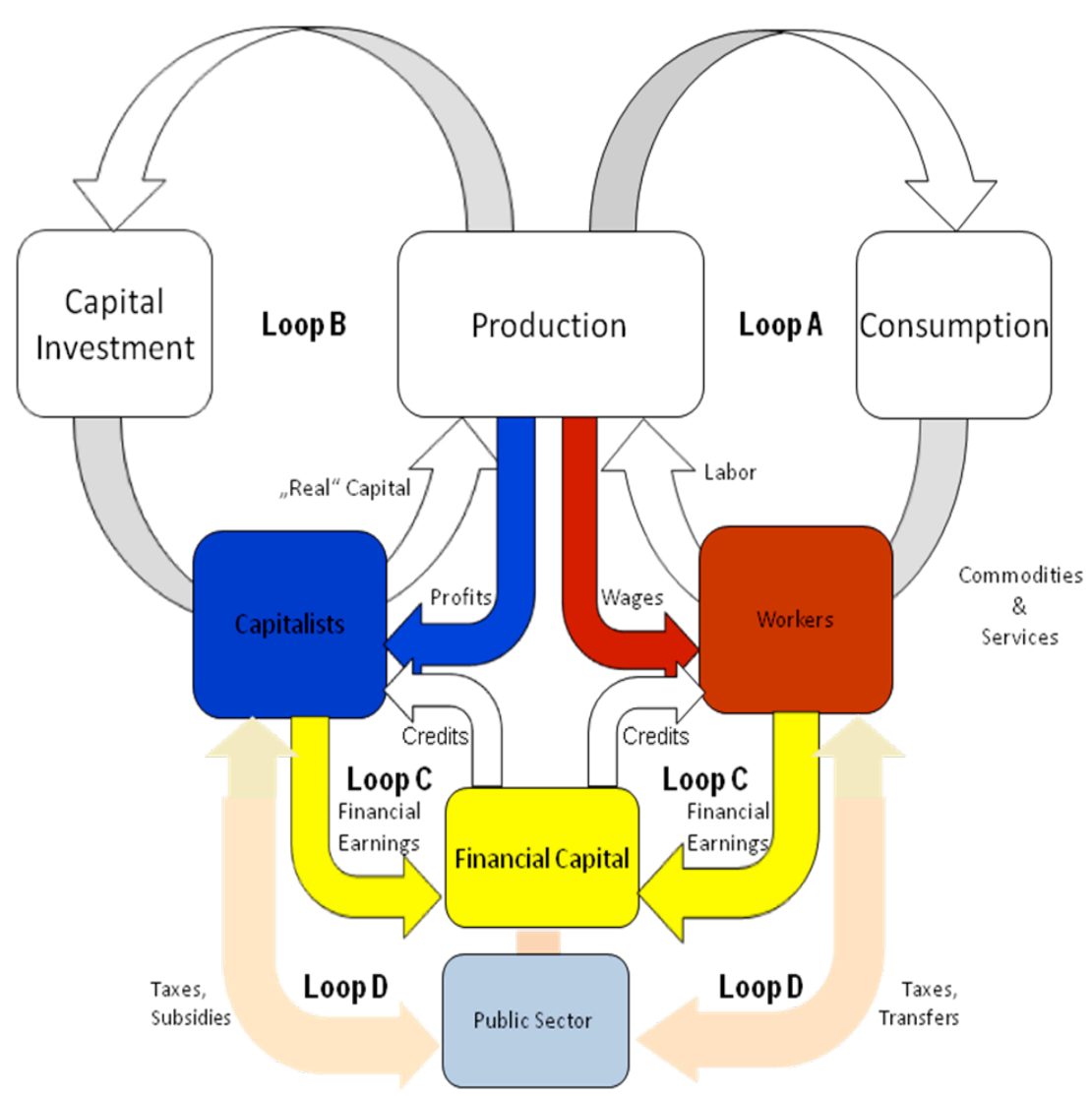

Figure 3: Capitalist economy with financial and public sectors (simplified) 
The prices of goods change from prices proportional to social labor (spent directly and indirectly) towards so called prices of production. The latter do no longer directly depend on the amount of labor incorporated in goods or services, but are set by a reasonable mark-up (rate of profit) on the costs of production. By competition in the markets the rates of profit show a tendency to converge, but by innovation and the foundation of new firms also a tendency to diverge can be expected (see Farjoun/Machover 1984). In the case of equalized profit rates we would end up with Marx's "production prices". This decribes an ideal situation where no capitalist would like to de-invest in "his/her" industry and re-invest in any other industry to earn higher profit rates. Prices of production describe a stylized equilibrium situation. They can be determined mathematically if one knows the socio-technical composition of the economy under investigation. Production prices represent an idealized "primary distribution" of income over the subjects of the economy. Marx' volumes 2 and 3 of "Das Kapital" $(1975,1979)$ describe the function and ends of a capitalist economy.

The fourth layer (and loop C in figure 3) includes financial markets of all kinds. Money, credit, debt, stocks, bonds, derivatives etc. can be found here. Money gets prices - interest rates - depending on the terms of credits, loans and deposits. Paying interest creates a "secondary distribution" of incomes. The re-allocation process of income has effects on the financial conditions of the subjects of the economy. It does not stem from commodity or services markets but from financial markets. Key reference is Hilferding's "Das Finanzkapital" (1910, reprint 1955), where the political and economic mechanisms and implications of the emerging financial sphere are discussed.

The description of a contemporary economy would be incomplete if we would not include the activities of the state (layer five in figure 1 and loop D in figure 3). Beside taxes and fees (public income), transfers and subsidies, public consumption and investment (public spending) the parapublic sector of social insurance is located here. The activities of the state influence strongly the "tertiary distribution" and shape the financial status and the economic activities of the economic subjects. The political and economic implications are described in the literature under the term "Stamokap" (State Monopolistic Capitalism, Lenin, 1917), where the state is no class-neutral actor but is in fact dominated by interests of "real" and financial capital.

A final step towards the concrete picture of the economy is signaled by layer 6 called information society. Economically speaking information society is characterized by an interesting process of commodification and commercialization of cultural activities of human beings (Fleissner, 2006) This means the transformation of information goods and information activities into commodities or services to be sold on the market. It is made possible by new information technologies digitizing cultural activities and fixing them on physical carriers (hard disks, CDs, DVDs), or transforming face-to-face communication activities into a commercial service (mobile communication). Technical and legal measures are undertaken to secure the market which would be destroyed otherwise by very cheap copying and distribution possibilities. A comprehensive reference to "information society" can be found in Manuel Castell's (1999) three volumes on the "Information Age".

How are the various layers linked to each other? The idea behind is that each higher layer controls and shapes the lower layers by its own "inner" law. Let us illustrate this by examples. Layer 3 organizes production along the principle of profitable production. New technologies will not be introduced if there is no profit to be expected. Layer 4 controls real economic activities according to the expected profits of financial capitalists. In fact, over the last decades financial capital in Germany and the U.S. accumulated wealth much faster than the "real" capitalists (Schulmeister, 2009, p. 23). Layer 5 subordinates each economic subject to its laws by taxation and transfers. As we can see from statistical data (Schulmeister, 2009, ibidem) the income distribution between wages and profits becomes more and more unequal: The rich become richer, the poor become (relatively) poorer. The recent financial crisis has shown that the economy is not sustainable, neither in social nor in environmental terms.

\section{Layer 1: Use values}

After this introduction into the basic structures of a capitalist economy the main features of a mathematical representation of the layers described above are presented. 
On the first layer we apply Leontief's input-output scheme to represent the economy in terms of use values (Leontief, 1966; Fleissner, 1993). We symbolize his scheme by convenient matrix notation. In an input-output table each row and each column represent one branch of production or firm (depending on the level of aggregation) of the economy. It reflects the degree of division of labor. The matrix of technical coefficients A represents the technology of the economy. The element $a_{i j}$ gives the amount of goods of industry i needed to produce one unit of output of industry $j$.

For simplicity we assume here matrix $\mathbf{A}$ is a square matrix representing $n$ industries ${ }^{1}$. Gross output $\mathbf{x}$ (a column vector with $n$ elements) contains the amounts of values in use in the economy. $\mathbf{x}$ can be split by kind of use of goods into the demand for intermediate goods $\mathbf{A x}$ and final demand $\mathbf{y}$.

$$
A x+y=x
$$

For reasons one will understand below we call (1) the primal problem. The rows of the scheme express the collection of goods produced and consumed in the economy.

Final demand $\mathbf{y}$ can be split it into consumption $\mathbf{c}$ and capital investment $\mathbf{s}$ (= surplus product in Marxian terms).

$$
\mathbf{y}=\mathbf{c}+\mathbf{s}
$$

To make computations easier later on, we express Leontief's input-output scheme in terms of matrices in analogy to the matrix of technical coefficients $A$ :

$$
A x+C x+S x=x
$$

where $\mathbf{x}$ represents the (column) vector of output, $\mathbf{A}, \mathbf{C}$, and $\mathbf{S}$ represent matrices of technical coefficients, consumption coefficients, and surplus coefficients respectively.

\section{Layer 2: Labor Values / Exchange Values}

The dual Leontief model deals with the unit prices

$$
p A+q=p,
$$

where $\mathbf{p}$ is the row vector of unit prices and $\mathbf{q}$ represents unit value added. If we substitute $\mathbf{q}$ by life labor input I needed to produce a unit of output, we get the basic formula how to compute labor values v - similar to Marx's writings in the first volume of Das Kapital:

$$
v A+I=v .
$$

In analogy to the primal problem we could split I into wages, $\mathbf{w}$, and profits $\pi$

$$
\mathbf{I}=\mathbf{w}+\pi .
$$

The above formulae reproduce Marx's concept of the composition of value incorporated a commodity. In his original symbols Marx wrote

$$
W=C+V+M,
$$

\footnotetext{
${ }^{1}$ Modern input-output data systems differentiate between groups of goods and groups of activities. In principle a rectangular scheme would be appropriate in this case. Usually empirical input-output tables contain also a quadratic version of the matrix - constructed under specific assumptions about technology.
} 
where $\mathrm{W}$ is the labor value, $\mathrm{C}$ constant capital, $\mathrm{V}$ variable capital and $\mathrm{M}$ surplus value. In our notation we arrive at the same result (neglecting fixed constant capital)

$$
\mathbf{v}=\mathbf{v A}+\mathbf{w}+\pi
$$

The total output $\mathbf{v x}$ in terms of labor time can be computed by right-multiplying the second equations by $\mathbf{x}$

$$
v A x+I x=v x
$$

The first term on the left hand side, vAx, is the value of all intermediary flows, the second term, vx, is an approximation of GDP.

If we introduce some simplifications (neglecting foreign trade, fixed capital, turnover times, and total non-wage income is assumed to be surplus value) we can apply the formulae to empirical data.

\section{Layer 3: Prices of Production}

To grasp for more realism we have to include features and effects of capitalism. In the third layer of figure 1 we allow for fixed capital, wages and competition between capitalists. Exploitation, profit and accumulation come into sight. Work becomes a marketable good.

Mathematically this means to solve the transformation problem from labor values $\mathbf{v}$ to prices of production $\mathbf{p}$ (both have to be expressed in the same units, either in labor time or money units). There are two methods to compute prices of production. In Das Kapital, volume two, Marx (1975) provided us with the following solution for $\mathbf{p}$ :

$$
\mathbf{p}=\mathbf{v}(\mathbf{K}+\mathbf{A}+\mathbf{C})(1+r), \text { where } r=\mathbf{v}(E-\mathbf{A}-\mathbf{C}) \mathbf{x} / \mathbf{v}(\mathbf{K}+\mathbf{A}+\mathbf{C}) \mathbf{x} \text { and } \mathbf{v}=\mathbf{I}(\mathbf{E}-\mathbf{A})^{-1}
$$

$\mathbf{K}$ is the matrix of capital coefficients per unit of output, $\mathbf{I}$ is the identity matrix with ones in its main diagonal, otherwise zeros, and $r$ is the average rate of profit.

This method can be generalized to an iteration process which leads us to the second solution proposed by von Bortkiewicz (1906/07) in the beginning of the $20^{\text {th }}$ century (which is equal to the solution of an eigenvector/eigenvalue problem). The generalized iteration scheme inspired by Marx is:

$$
p_{i}(K+A+C)\left(1+r_{i}\right)=p_{i+1}
$$

where $r_{i}=p_{i}(E-A-C) x / p_{i}(K+A+C) x . K$ is the matrix of capital coefficients per unit of output and $r_{i}$ is the average profit rate at iteration step i. We neglect different turnover times and assume they are all equal to one.

The link to labor time is kept up because the iteration scheme starts from the solution of equation (3) for $\mathbf{v}$

$$
\begin{gathered}
\mathbf{p}_{0}=\mathbf{v}=\mathbf{I}(\mathbf{I}-\mathbf{A})^{-1}, \text { where } \\
\mathbf{r}_{0}=\mathbf{p}_{0}(\mathbf{E}-\mathbf{A}-\mathbf{C}) \mathbf{x} / \mathbf{p}_{0}(\mathbf{K}+\mathbf{A}+\mathbf{C}) \mathbf{x}
\end{gathered}
$$

Elsewhere (Fleissner, 2008) I have shown empirical results for layers 1, 2 and 3 for the Austria economy 2003, also under the assumption that services do not contribute to the surplus value. 


\section{Layers 4 and 5: Money, Banks and the State}

Climbing up to the next layers of an economy is not an easy task, in particular if one is devoted to Marxian thinking and to his labor theory of value. The question is, at what place in an input-output system we can introduce money. One possible location is the emergence of disequilibria.

In a first version of the model we assumed that the consumers buy their consumption only out of wages and the firms buy their capital investment out of their profits. This can be built into the model by conditions for clearing the markets.

\section{Wages equal consumption:}

$$
w x=p C x=p c
$$

\section{Profits equal capital investment:}

$$
\pi x=p S x=p s .
$$

If we go up to layer 4 we have to get rid of these assumptions and allow for a discrepancy between wage sum and consumption as well as between profits and capital investment. The gap is assumed to be financed by credits which change the money stocks $m$ of industries, private households or the state. If money resources are higher than consumption or investment the savings go as deposits to the banks sector. At the same moment, economic subjects earn interest from their deposits or have to pay interest for their debt.

To be able to use a simpler notation from here on the meaning of the vectors and matrices are no longer on unit level, but on the level of money terms/turnover (price times number of physical units).

Money savings/increase of debt of households, $\mathbf{s}_{\mathrm{hh}}$, are given by the following relations

$$
\begin{array}{ll}
\mathbf{s}_{\mathrm{hh}, \mathrm{t}}=\mathbf{w}_{\mathrm{t}}-\mathbf{1}^{\prime} \mathbf{C}_{\mathrm{t}}+\mathrm{rl}, \mathrm{t} \mathbf{m}_{\mathrm{hh}, \mathrm{t}} & \text { if } \mathbf{m}_{\mathrm{hh}, \mathrm{t}}>0 \\
\mathbf{s}_{\mathrm{hh}, \mathrm{t}}=\mathbf{w}_{\mathrm{t}}-\mathbf{1}^{\prime} \mathbf{C}_{\mathrm{t}}+\mathrm{rb}, \mathrm{t} \mathbf{m}_{\mathrm{hh}, \mathrm{t}} & \text { if } \mathbf{m}_{\mathrm{hh}, \mathrm{t}}<0
\end{array}
$$

where $r$ is the interest rate for lending money to banks, rb the interest rate for borrowing from banks, $\mathrm{r} /<\mathrm{rb}$

Similarly, we have money savings/increase of debt of firms, $\mathbf{s} \mathbf{f}$, as a result of profits, minus capital investment and borrowing/lending money (time indices suppressed)

$$
\begin{array}{ll}
\mathbf{s}_{\mathrm{f}}=\pi-\mathbf{1}^{\prime} \mathbf{S}+\mathrm{rl}_{\mathrm{f}} \mathbf{m}_{\mathrm{f}} & \text { if } \mathbf{m}_{\mathrm{f}}>0 \\
\mathbf{s}_{\mathrm{f}}=\pi-\mathbf{1}^{\prime} \mathbf{S}+\mathrm{rb}_{\mathrm{f}} \mathbf{m}_{\mathrm{f}} & \text { if } \mathbf{m}_{\mathrm{f}}<0
\end{array}
$$

\section{Dynamic Relations}

While the above equations were restricted to flow equations, the dynamic equations need the extension of the model toward stock variables. As we would like to represent physical capital as well as money capital, we have to include corresponding dynamic equations to connect the stock values at consecutive points in time. We add a stock matrix for physical capital in absolute terms (not on unit level), $\mathbf{K}_{\mathrm{a}}$, and a row vector for money capital, $\mathbf{m}$, at time $\mathrm{t}$.

\section{Physical capital}

The dynamics for physical capital is given by

$$
\mathbf{K}_{\mathrm{a}, \mathrm{t}+1}=\mathbf{K}_{\mathrm{a}, \mathrm{t}}+\mathbf{S}_{\mathrm{n}}=\mathbf{K}_{\mathrm{a}, \mathrm{t}}+\left(\mathbf{S}-\mathbf{S}_{\mathrm{d}}\right),
$$


where $\mathbf{S}_{n}$ is the matrix of net capital investment per time unit, and $\mathbf{S}_{d}$ the scrap matrix (or depreciation matrix) of capital. The relation between gross and net investment is given by

$$
S_{n}=\mathbf{S}-S_{d}
$$

Household are also holding stocks of physical capital, Khh, like cars, houses and the like.

\section{Money capital}

The money capital stock of firms, banks and the government debt can be represented by a row vector $\mathbf{m}_{\mathrm{f}, \mathrm{t}}$, the one of households by $\mathbf{m}_{\mathrm{hh}, \mathrm{t}}$

Money(+)/Debt(-) stocks of households, $\mathbf{m}_{\mathrm{hh}, \mathrm{t}}$, at time $\mathrm{t}$, is given by

$$
\mathbf{m}_{\mathrm{hh}, \mathrm{t+1}}=\mathbf{m}_{\mathrm{hh}, \mathrm{t}}+\mathbf{s}_{\mathrm{hh}, \mathrm{t}}
$$

Money(+)/Debt(-) stocks of firms, $\mathbf{m f}, \mathrm{t}$, at time $\mathrm{t}$

$$
\mathbf{m}_{\mathrm{f}, \mathrm{t}+1}=\mathbf{m}_{\mathrm{hh}, \mathrm{t}}+\mathbf{s}_{\mathrm{f}, \mathrm{t}}
$$

In the preliminary version of the model the decision mechanisms of the branches of production, of banks, of the state and of the households are not very elaborated, but it is planned to implement decision mechanisms as described in (Ayres \& Martinás, 2006) or (Kozub, 1993).

\section{Net income of banks and the state}

The sectors banks and state need special treatment, because their total output depends on the redistribution of direct income of other sectors to or from them. According to the accounting standards of the European Union in the input-output tables domestic production is shown explicitly and in detail, while the distribution side of value added is not elaborated at all. Primary distribution is given by consumption of fixed capital, gross wages (including social security contributions) and operating surplus (gross).In this version of the model the primary distribution is transformed into a generic type of secondary distribution where banks and the state have a specific role. In the primary distribution banks earn only fees for their services, and the state receives only remuneration for its production activities. Interest paid by non-banks (firms and households) are part of the secondary distribution, as are all kinds of taxes. By creating the secondary distribution of value added its total sum remains constant, while the income distribution is changed.

In the model a finer breakdown of value added is given using the following categories: consumption of fixed capital (depreciation), indirect taxes, profit taxes, wage taxes, operating surplus (net) and net wage.

Taxes are the product of a tax rate times a tax base. Profit taxes are based on non-negative gross profits. In the preliminary version of the model neither social insurance is yet included nor are transfers and subsidies.

The financial assets/debts of firms, households and state are held by the banks. Assets are rewarded by banks with an interest rate r_borrowing, credits have to be paid for with an interest rate r_lending (r_lending > r_borrowing). The payments of interest are deducted from / added to the surplus variables or wage income. Of course, the redistribution does not change the amount of total GDP.

In this simplified version the income of banks is given by the sum of all interest payments of all sectors including the household and government sectors minus all interest payments of the bank for deposits of firms, households of government (if any). : 
The following control variables are available, which allow for a change of the distribution of value added:

$\begin{array}{lll}\text { - } & \text { r_b } & \text { interest rate for credits } \\ \text { - } & \text { r_l } & \text { interest rate for assets at banks } \\ \text { - } & \text { t_ind } & \text { tax rate of indirect taxes } \\ \text { - } & \text { t_profits } & \text { tax rate of profits } \\ \text { - } & \text { t_wages } & \text { tax rate on wages } \\ \text { - } & \text { deprec_rate } & \text { depreciation rate }\end{array}$

In addition, one can control the fraction of public investment on total investment and a leverage_factor, which limits the maximum amount of credits given by banks with respect to their financial assets.

\section{Growth dynamics}

For each sector and for households a stock of fixed capital (physical capital expressed in currency units) and a stock of financial assets/debt is given. Fixed physical capital of firms, of the state or of the households is updated annually by net private or public investment, financial assets are updated by the difference of surplus (including depreciation, minus taxes and interests) and investment. For the households of each sector assets are updated by the difference of net wages plus capital income minus consumption. The updated stocks represent the basis for production of the following year.

In the current version of the model a simple price mechanism is built in to match demand to supply. In our case supply is given by capital stock times capital productivity. Unfortunately, demand $x_{d}$ is not always equal to supply $x_{s}$, so a change in prices will fix this difficulty to stimulate or to reduce demand such that it equals supply. For each sector the following equations hold:

$$
\begin{gathered}
x_{s}=x_{d}{ }^{*} p^{(- \text {alfa })} \\
p^{\text {alfa }}=x_{d} / x_{s}=>p=\left(x_{d} / x_{s}\right)^{1 / a l f a}
\end{gathered}
$$

In the context of a standardized input matrix demand is given by

$$
\mathbf{x}_{\mathrm{d}}=(\mathbf{A}+\mathbf{C}+\mathbf{S}) \mathbf{x}_{\mathrm{s}}
$$

where $\mathbf{x}_{\mathbf{s}}$ is the vector of new output. Preliminary results of the simulation model based on stylized facts are given in Fleissner (2009).

\section{Layer 6: Information Goods and Services are Commercialized}

This layer is less important from the point of view of mathematical modeling, because it just adds new goods and services to the economy, leaving the mathematical structures invariant. But from a political point of view the new technologies should not be underestimated (Fleissner, 2007). For the first time in history digital technologies, the Internet and Mobile Communication can be used to exchange information and establish global communication among people. The world's wealth could be distributed according to the needs of people, not of capitalists only.

For this reason it will become necessary - without getting rid of the achievements of the past - to establish a new political institution which is able to take over control of all layers presented in the paper. The open question is the guiding principle of this institution. It could be a new regime in the interest of minorities, it could become a fascist dictatorship, but it could also become a democratic, transparent institution in the interest of the many, thus preventing the collapse of our planet. Information technologies will assist this transformation to the worse or to the better. 


\section{References}

Ayres, R. U., \& Martinás, K. (2006). On the reappraisal of microeconomics: economic growth and change in a material world. Cheltenham: Edward Elgar.

Ayres, R. U., Fleissner, P., \& Martinás, K. (2010). Energy, money and production. Retrieved July 20, 2010 from http://peter.fleissner.org/MathMod/Energy,MoneyandProduction.pdf

Bortkiewicz, L. v. (1906/1907). Wertrechnung und Preisrechung im Marxschen System. Published in three parts in: Archiv für Sozialwissenschaft und Sozialpolitik, Part I: Vol. XXIII, Heft 1, 1906: pp. 1-50. The remaining parts were published in: Vol. XXV, 1907: pp. 10-51 and pp. 445-488.

Castells, M. (1999). The information age - Economy, society, and culture. Paperback edition. 3 Volumes. Oxford: WileyBlackwell

Fleissner, P. (2008). Marx begegnet Leontief - Neuere Gesichtspunkte der Arbeitswertlehre. Wirtschaft und Gesellschaft 34(3), 361-396.

Fleissner, P., \& Romano, V. (Ed.) (2007). Digitale Medien - neue Möglichkeiten für Demokratie und Partizipation. Berlin: trafo Verlag.

Fleissner, P. (2010, July 20). The commodification of knowledge in the global information society. Retrieved from http://www.wrpe.org/WAPE/WAPE\%20Papers\%202006/Peter_Fleissner.pdf

Fleissner, P. et al. (1993). Input-Output-Analyse. Wien: Springer.

Hilferding, R. (1955). Das Finanzkapital - Eine Studie über die jüngste Entwicklung des Kapitalismus. Berlin: Dietz Verlag.

Kozub, D. (2010). Microsimulation model of national economy. MSMNE-02. Retrieved July 20, 2010 from http://dankozub.com/simulation/index.html

Lenin, W. I. (1917). Werke. Das Agrarprogramm der Sozialdemokratie in der ersten russischen Revolution von 1905 bis 1907. Epilogue. Reprint 1972 in German. Berlin: Dietz Verlag.

Leontief, W. (1966). Input-output economics. Oxford: Oxford University Press.

Luenberger, D. G. (1969): Optimization by vector space methods. New York: Wiley.

Marx K., \& Engels, F. (1979). Werke. Das Kapital Band 1. Vol 23. Berlin: Dietz Verlag.

Marx K., \& Engels, F. (1975). Werke. Das Kapital Band 2. Vol 24. Berlin: Dietz Verlag.

Marx K., \& Engels, F. (1979). Werke. Das Kapital Band 3. Vol 25. Berlin: Dietz Verlag.

Samuelson, P. (1971). Understanding the marxian notion of exploitation: A summary of the so-called transformation problem between marxian values and competitive prices. Journal of Economic Literature 9(2): 399-431.

Schulmeister, S. (2009). Die neue Weltwirtschaftskrise - Ursachen, Folgen, Gegenstrategien. Arbeiterkammer: Wien. Smith, A. (1789). An inquiry into the nature and causes of the wealth of nations. German reprint of the fifth edition (1978). München: DTV Verlag.

\section{About the Author}

Peter Karl Fleissner

born 1944, retired from his chair on Social Cybernetics of the Institute of Design and Assessment of New Technologies at the Technical University Vienna, in October 2006, after seven years of work for the European Union (1997-2000: Head of the Department "Technology, Employment, Competitiveness and Society" of the Seville based Institute for Prospective Technological Studies (IPTS) of the Joint Research Centre of the European Commission in Spain; 2000-2004: Head of the Department "Research and Networking" of the European Monitoring Centre on Racism and Xenophobia - EUMC). Before, he had worked for the Austrian Academy of Sciences; the International Institute for Applied Systems Analysis (IIASA), Laxenburg, Austria; as research scholar at the Massachusetts Institute of Technology; and at the Institute for Advanced Studies, Vienna, Austria. He continues work as consultant (simulating pension schemes for the Austrian Chamber of Labor, developing long term socio-economic and ecological models and as lecturer at TU Vienna and University of Klagenfurt.

Selected publications: BruchStücke (co-editor Wanek, N., 2009); Digitale Medien - Neue Möglichkeiten für Demokratie und Partizipation? (with Romano, V., 2007); Philosophy of culture and the politics of electronic networking, 2 volumes (with Nyíri, J. C., 1999); Data security and privacy (with Choc, M. , 1997); Men shall not live by bit alone (with Hofkirchner, W., Müller, H., Pohl, M., \& Stary, Ch., 1996); The transformation of slovakia, 1994; Input-output analysis, 1993; East german economy in transition (with Ludwig, U., 1992). Further information: http://members.chello.at/gre/fleissner/default.htm. E-mail: fleissner@arrakis.es. 